\title{
The clinical and prognostic significance of LGR5 in GC: A meta-analysis of IHC assay and bioinformatics analysis
}

\author{
Fei GUO ${ }^{1}$, Tao YANG ${ }^{1}$, Rende GUO ${ }^{1}$, Yu WANG ${ }^{2, *}$ \\ ${ }^{1}$ Department of General Surgery, Tianjin First Central Hospital, Tianjin, China; ${ }^{2}$ Department of Emergency, Tianjin First Central Hospital, \\ Tianjin, China \\ ${ }^{*}$ Correspondence: $g$ f17788430@sohu.com
}

Received July 14, 2020 / Accepted March 3, 2021

\begin{abstract}
Recently, leucine-rich repeat-containing G-protein-coupled receptor 5 (LGR5) is a newly identified cancer stem cell marker and Wnt target gene. However, the role of LGR5 in gastric cancer (GC) remains uncertain. This study was performed to investigate the effect of LGR5 expression in GC. The eligible studies were searched via electronic databases. The odds ratios (ORs) with 95\% confidence intervals (CIs) or hazard ratios (HRs) with 95\% CIs were applied to estimate the effect of LGR5. Further bioinformatics validation data were used to confirm our results. Eleven studies consisting of 2,646 GC patients were identified. LGR5 expression was not associated with age, gender, tumor stage, T stage, tumor size, lymphatic invasion, lymph node metastasis, and distal metastasis. LGR5 expression was related to tumor type (intestinal vs. diffuse: $\mathrm{OR}=2.25, \mathrm{p}=0.032$ ). LGR5 expression was negatively correlated with tumor grade (grade 3-4 vs. grade $1-2$ : $\mathrm{OR}=0.40, \mathrm{p}=0.033$ ). Further TCGA validation data also showed similar findings, and LGR5 expression was also found to have a negative association with tumor grade. LGR5 expression was associated with worse overall survival (OS) using multivariate Cox analysis ( $\mathrm{HR}=2.54$, $\mathrm{p}=0.009$ ). Further bioinformatics data showed that LGR5 expression was still correlated with shorter OS in 876 GCs. LGR5 expression was negatively correlated with tumor grade and its expression was higher in intestinal-type than in diffuse-type. Moreover, LGR5 may be a potential prognostic factor for survival prediction in GC.
\end{abstract}

Key words: gastric cancer, LGR5, cancer stem cell, clinical prognosis

Gastric cancer (GC) is one of the most common human cancers and the third cause of cancer-related mortality in the world [1]. According to the GLOBOCAN cancer estimates, approximately 1,033,701 new cases with GC are diagnosed, and approximately 782,685 cases are expected to die of GC worldwide [1]. Although multimodal treatment regimens (i.e., surgery, chemotherapy, radiotherapy, targeted therapy, and immune therapy) have significantly improved survival in patients with GC, most patients are usually diagnosed in advanced stages of the disease, the 5-year survival rate of advanced GC remains very low ( 26\%) [2-5]. Therefore, the identification of novel molecular biomarkers is needed to improve the prognosis and therapeutic efficacy of patients with GC.

Cancer stem cells (CSCs), a small population of tumor cells, have the potential of self-renewal capacity, aberrant proliferation and differentiation, and treatment resistance [6-9]. CSCs are responsible for tumor progression, metastasis, and worse prognosis [10-12]. Leucine-rich repeatcontaining G-protein-coupled receptor 5 (LGR5) is a member of the G protein-coupled receptor (GPCR) that belongs to the subfamily of glycoprotein hormone receptors $[13,14]$. LGR5 has initially been identified as an intestinal marker of CSCs [15]. LGR5 is also a newly identified Wnt target gene, as a critical effector of Wnt signaling with R-spondin (Rspo), Znrf3, and Rnf43, which enhances Wnt/ beta-catenin signaling $[16,17]$. The Rspo-LGR5 axis has a crucial role in gastric-gland homeostasis and LGR5 acts as a stem cell factor in the stomach [18]. Aberrant LGR5 expression could regulate the epithelial cell phenotype and contributes to cell survival of hepatocellular carcinoma [19]. LGR5 plays an important role in tumor formation and cell proliferation via Hedgehog signaling in basal cell carcinoma [20]. LGR5 regulates colorectal cancer cell proliferation and survival, and LGR5 is correlated with poor prognosis of colorectal cancer $[21,22]$. Recently, gastric LGR5(+) stem cells as cancer-propagating cells can promote malignant progression [23]. Therefore, more understanding roles of LGR5 in patients with GC are necessary.

The previous meta-analysis only included six studies published before 2014, with a small study population of GC 
$(n=1253)$ [24]. However, the significance of LGR5 in GC is not fully understood. Recently, many studies investigate the role of LGR5 in GC [25-29]. In this work, our meta-analysis involving a larger cohort with 2646 patients was conducted to investigate the clinicopathological and prognostic value of LGR5 in GC. Additionally, the bioinformatics data were also first used to validate our results in the independent data of 1244 GC cases.

\section{Materials and methods}

Literature search. This meta-analysis was performed based on the guidelines in the Preferred Reporting Items for Systematic Reviews and Meta-Analyses (PRISMA Supplementary Figures S1 and S2) statement [30]. A literature search was conducted to identify studies on the role of LGR5 in GC before November 17, 2019. We searched the PubMed, EMBASE, Web of Science, and Cochrane Library databases using the following key words and search terms: "LGR5 OR Leucine-rich repeat-containing $G$ protein-coupled receptor 5 OR GRP49”, “stomach OR gastric", "cancer OR tumor OR carcinoma OR neoplasm". Besides, the references of the eligible full-length papers were also scanned to identify the candidate studies.

Eligibility criteria. The eligible study met the following inclusion criteria: 1) patient diagnoses were confirmed with GC by histopathological identification; 2) immunohistochemistry (IHC) detection was applied to determine the expression of LGR5; 3) studies reported the correlation between LGR5 and clinicopathological parameters; 4) studies reported the relationship between LGR5 and the prognosis using multivariate Cox analysis. When multiple articles were published by the same institute based on the overlapping patient population, only the article with the largest sample sizes or the most recent paper was selected. The main exclusion criteria for this meta-analysis included: 1) studies in cell or animal subjects; 2) reviews, conference abstracts, case reports, or letters; 3 ) studies with insufficient information on LGR5 in GC.

Data extraction. The following information was extracted using a standardized form, including first author's surname, year of publication, country, ethnicity, detection method, median or mean age, antibody information, the cut-off values, sample size, LGR5 frequency, the clinicopathological parameters such as age, gender, tumor stage, tumor grade, tumor size, lymphatic invasion, tumor type, T stage, lymph node metastasis, and distal metastasis, and the prognosis of multivariate Cox analysis (overall survival: OS and cancerspecific survival). Any discrepancies were settled through all authors' discussion.

Meta-analysis. Meta-analysis was performed using Stata software, version 12.0 (Stata Corp., College Station, TX, USA). The pooled odds ratios (ORs) and 95\% confidence intervals (CIs) were used to estimate the relationship between LGR5 expression and the clinicopathological features of GC.
The pooled hazard ratios (HRs) and their 95\% CIs were applied to evaluate the prognostic role of LGR5 expression on GC patients using multivariate Cox analysis. The randomeffects model was employed in this meta-analysis. The statistical heterogeneity was assessed by observing Cochran's Q statistic [31]; a Q-test of p-value $<0.1$ indicated significant heterogeneity. When substantial heterogeneity was observed, sensitivity analyses were conducted to estimate the influence of the re-calculated results and heterogeneity based on the omission of a single study. The potential publication bias was measured using Egger's test for the results with more than five studies [32].

Validation from bioinformatics study. The clinical information of patients with GC and expression data of LGR5 were downloaded from The Cancer Genome Atlas (TCGA) (https://portal.gdc.cancer.gov/). The raw expression values (HTSeq-Counts) were normalized using the Trimmed Mean of M-values (TMM) method via the edgeR package. Finally, the expression data of $368 \mathrm{GC}$ patients and clinical data were included. Moreover, Kaplan-Meier survival curve was used to determine the survival difference of LGR5 expression (210393_at) [33] (http://kmplot.com/analysis/index. php? $\mathrm{p}=$ background), including 876 GC patients from microarray-based transcriptomic data. The association between LGR5 expression and the clinicopathological characters was performed using the Wilcoxon signed-rank test. TCGA data were performed using the R software version 3.5.1 (Institute for Statistics and Mathematics, Vienna, Austria).

\section{Results}

Characteristics of the included studies. The detailed literature search procedure and study selection are shown in Figure 1. Through screening title and abstract and

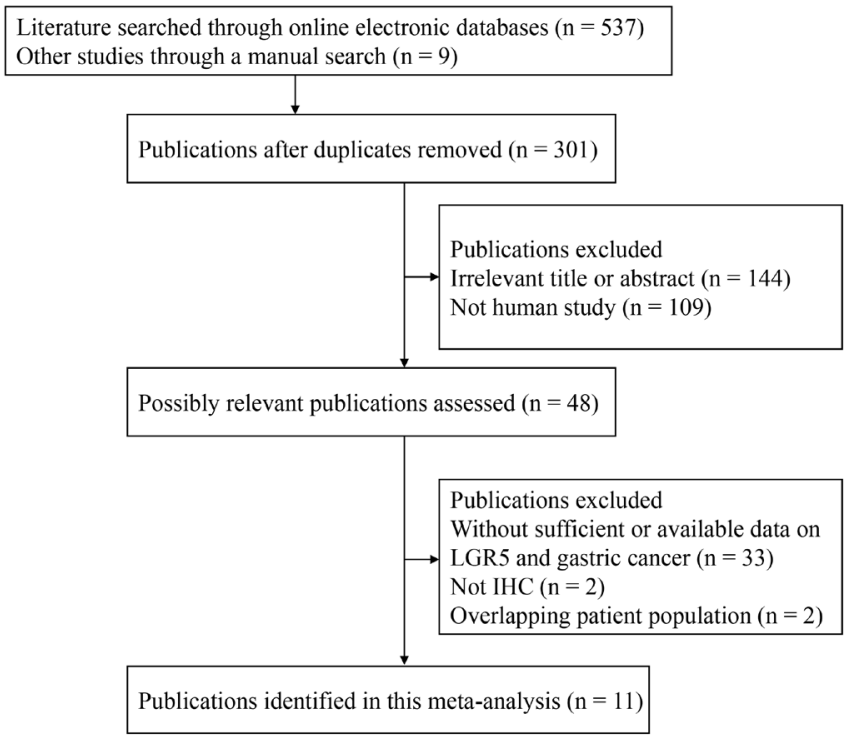

Figure 1. Flow diagram of the study selection process. 
Table 1. Main characteristics of the included studies.

\begin{tabular}{|c|c|c|c|c|c|c|c|c|c|c|c|}
\hline $\begin{array}{l}\text { First } \\
\text { author }\end{array}$ & Country & Ethnicity & Age & Stage & Antibody & $\begin{array}{c}\text { Sources } \\
\text { of antibody }\end{array}$ & Staining & $\begin{array}{c}\text { Cut-off values } \\
\text { of IHC }\end{array}$ & $\begin{array}{c}\text { Case } \\
\mathrm{N}(\mathrm{E}+\%)\end{array}$ & $\begin{array}{l}\text { Clinical } \\
\text { features }\end{array}$ & $\begin{array}{l}\text { MA- } \\
\text { survival }\end{array}$ \\
\hline $\begin{array}{l}\text { Simon } \\
2012\end{array}$ & Germany & Caucasian & 68 & NA & anti-LGR5 & $\begin{array}{l}\text { LGR5com, 1:400; Ab- } \\
\text { cam, Inc., Cambridge, } \\
\text { MA, USA }\end{array}$ & $\begin{array}{l}\text { Cytoplasm/ } \\
\text { membrane }\end{array}$ & weak-strong & $\begin{array}{c}487 \\
(50.1 \%)\end{array}$ & Yes & \\
\hline $\begin{array}{l}\mathrm{Bu} \\
2013\end{array}$ & China & Asian & 61 & $1-4$ & anti-LGR5 & $\begin{array}{l}\text { AP2745d, Abgent, San } \\
\text { Diego, CA, USA; at } \\
\text { 1:10 dilution }\end{array}$ & $\begin{array}{l}\text { Cytoplasm/ } \\
\text { membrane }\end{array}$ & $\geq 1$ score & $\begin{array}{c}257 \\
(51.8 \%)\end{array}$ & Yes & \\
\hline $\begin{array}{l}\mathrm{Wu} \\
2013\end{array}$ & China & Asian & NA & NA & anti-LGR5 & dilution 1:300; Abcam & NA & weak-strong & $\begin{array}{c}160 \\
(61.3 \%)\end{array}$ & Yes & \\
\hline $\begin{array}{l}\text { Jang } \\
2013\end{array}$ & Korea & Asian & NA & NA & anti-LGR5 & NA & NA & NA & $\begin{array}{c}68 \\
(45.6 \%)\end{array}$ & Yes & \\
\hline $\begin{array}{l}\mathrm{Xi} \\
2014\end{array}$ & China & Asian & 65 & $1-4$ & anti-LGR5 & $\begin{array}{l}\text { 1:50 dilution, } \\
\text { ab75850; Abcam, } \\
\text { Cambridge, MA, USA }\end{array}$ & Cytoplasm & $\geq 2$ score & $\begin{array}{c}318 \\
(54.1 \%)\end{array}$ & Yes & OS \\
\hline $\begin{array}{l}\mathrm{Xi} \\
2014\end{array}$ & China & Asian & 62.5 & $1-3$ & anti-LG R5 & $\begin{array}{l}\text { 1:50; Abcam, Cam- } \\
\text { bridge, MA, USA }\end{array}$ & Cytoplasm & $\geq 2$ score & $\begin{array}{c}68 \\
(66.2 \%)\end{array}$ & Yes & OS \\
\hline $\begin{array}{l}\text { Zhou } \\
2015\end{array}$ & China & Asian & 59.6 & $1-4$ & anti-LGR5 & Abcam, USA & $\begin{array}{l}\text { Cytoplasm/ } \\
\text { membrane }\end{array}$ & $>2$ score & $\begin{array}{c}261 \\
(38.7 \%)\end{array}$ & Yes & \\
\hline $\begin{array}{l}\text { Chen } \\
2016\end{array}$ & China & Asian & NA & $1-4$ & anti-LGR5 & 1:60, Abcam & Cytoplasm & 0 point & $\begin{array}{c}377 \\
(26.8 \%)\end{array}$ & Yes & \\
\hline $\begin{array}{l}\text { Kalantari } \\
2017\end{array}$ & Iran & Caucasian & 63 & $1-4$ & anti-LGR5 & $\begin{array}{l}\text { 1:1000 dilution, } \\
\text { ab71225; Abcam, UK }\end{array}$ & $\begin{array}{l}\text { Cytoplasm/ } \\
\text { membrane }\end{array}$ & $>106 \mathrm{H}$-score & $\begin{array}{c}94 \\
(50 \%)\end{array}$ & Yes & \\
\hline $\begin{array}{l}\text { Choi } \\
2017\end{array}$ & Korea & Asian & NA & $1-4$ & anti-LGR5 & 1:10, Abcam & Cytoplasm & NA & $\begin{array}{c}456 \\
(23.5 \%)\end{array}$ & Yes & CSS \\
\hline $\begin{array}{l}\text { Liu } \\
2019\end{array}$ & China & Asian & 60 & $1-3$ & anti-LGR5 & $\begin{array}{l}\text { 1:800; Abcam- } \\
\text { ab75732, USA }\end{array}$ & NA & $\geq 7$ score & $\begin{array}{c}100 \\
(53 \%) \\
\end{array}$ & Yes & OS \\
\hline
\end{tabular}

Abbreviations: NA-not applicable; N-the number of the study population; E+-positive expression; H-score-Histochemical score; IHC-immunohistochemistry; MA-multivariate Cox analysis; CSS-cancer-specific survival; OS-overall survival

reviewing the full-text articles, finally, a total of 11 studies consisting of 2646 patients with GC met the inclusion criteria were included in this meta-analysis [25-29, 34-39]. The eligible studies were published between 2012 and 2019, and they were conducted in China, Germany, Korea, and Iran. All 11 eligible articles evaluated the relationship of LGR5 expression with various clinicopathological parameters, including age, gender, tumor stage, tumor grade, tumor size, lymphatic invasion, tumor type, $\mathrm{T}$ stage, lymph node metastasis, and distal metastasis. Four studies assessed the prognostic value of LGR5 expression on GC based on multivariate Cox analysis. The baseline characteristics of the included studies are summarized in Table 1 and Supplementary Table S1.

Association between LGR5 expression and various clinicopathological features. The results showed that LGR5 expression was not correlated with age $(n=7$ studies with 1,837 cases; $\geq 60$ vs. $\leq 60$ years: $\mathrm{OR}=1.10,95 \% \mathrm{CI}=0.70-1.73$, $\mathrm{p}=0.671)$ and gender $(\mathrm{n}=10$ studies with 2,486 cases; male vs. female: $\mathrm{OR}=1.28,95 \% \mathrm{CI}=0.93-1.76, \mathrm{p}=0.129$; Figure 2).

Data from 8 studies with 1,922 cases showed no association between LGR5 expression and tumor stage (stage 3-4 vs. stage $1-2$ : $O R=1.59,95 \% \mathrm{CI}=0.72-3.52, \mathrm{p}=0.249)$. LGR5 expression was negatively associated with advanced tumor grade (grade $3-4$ vs. grade $1-2: \mathrm{OR}=0.40,95 \% \mathrm{CI}=0.17-0.93$, $\mathrm{p}=0.033$ ), including 9 studies with 2,026 cases (Figure 3).

The results demonstrated that LGR5 expression was not associated with $\mathrm{T}$ stage $(\mathrm{n}=8$ studies with 2,159 cases; $\mathrm{T}$ 3-4 vs. $\mathrm{T}$ 1-2: $\mathrm{OR}=1.27,95 \% \mathrm{CI}=0.68-2.37, \mathrm{p}=0.446)$, lymph node metastasis $(n=9$ studies with 2,364 cases; positive vs. negative: $\mathrm{OR}=1.56,95 \% \mathrm{CI}=0.95-2.56, \mathrm{p}=0.078$ ), and distal metastasis $(n=4$ studies with 1,399 cases; positive vs. negative: $\mathrm{OR}=1.06,95 \% \mathrm{CI}=0.39-2.88, \mathrm{p}=0.913$; Figure 4).

Data demonstrated no significant correlation between LGR5 expression and tumor size ( $\mathrm{n}=5$ studies with 1,232 cases; $\geq 4$ vs. $\leq 4 \mathrm{~cm}: \mathrm{OR}=1.54,95 \% \mathrm{CI}=0.99-2.41, \mathrm{p}=0.056$ ) and lymphatic invasion $(n=2$ studies with 710 cases; positive vs. negative: $\mathrm{OR}=0.72,95 \% \mathrm{CI}=0.52-1.01, \mathrm{p}=0.055$; Figure 5). Data from three studies with 728 cases showed that LGR5 expression was correlated with tumor type (intestinal vs. diffuse: $\mathrm{OR}=2.25,95 \% \mathrm{CI}=1.07-4.72, \mathrm{p}=0.032$; Figure 5).

Prognostic role of LGR5 expression using multivariate Cox analysis. LGR5 expression was not correlated with cancer-specific survival in 456 patients with $\mathrm{GC}(\mathrm{HR}=1.025$, 95\% CI=0.679-1.548) [26]. LGR5 expression was correlated with poor overall survival (OS) in three studies with 486 cases $(\mathrm{HR}=2.54,95 \% \mathrm{CI}=1.26-5.11, \mathrm{p}=0.009$; Figure 6). 


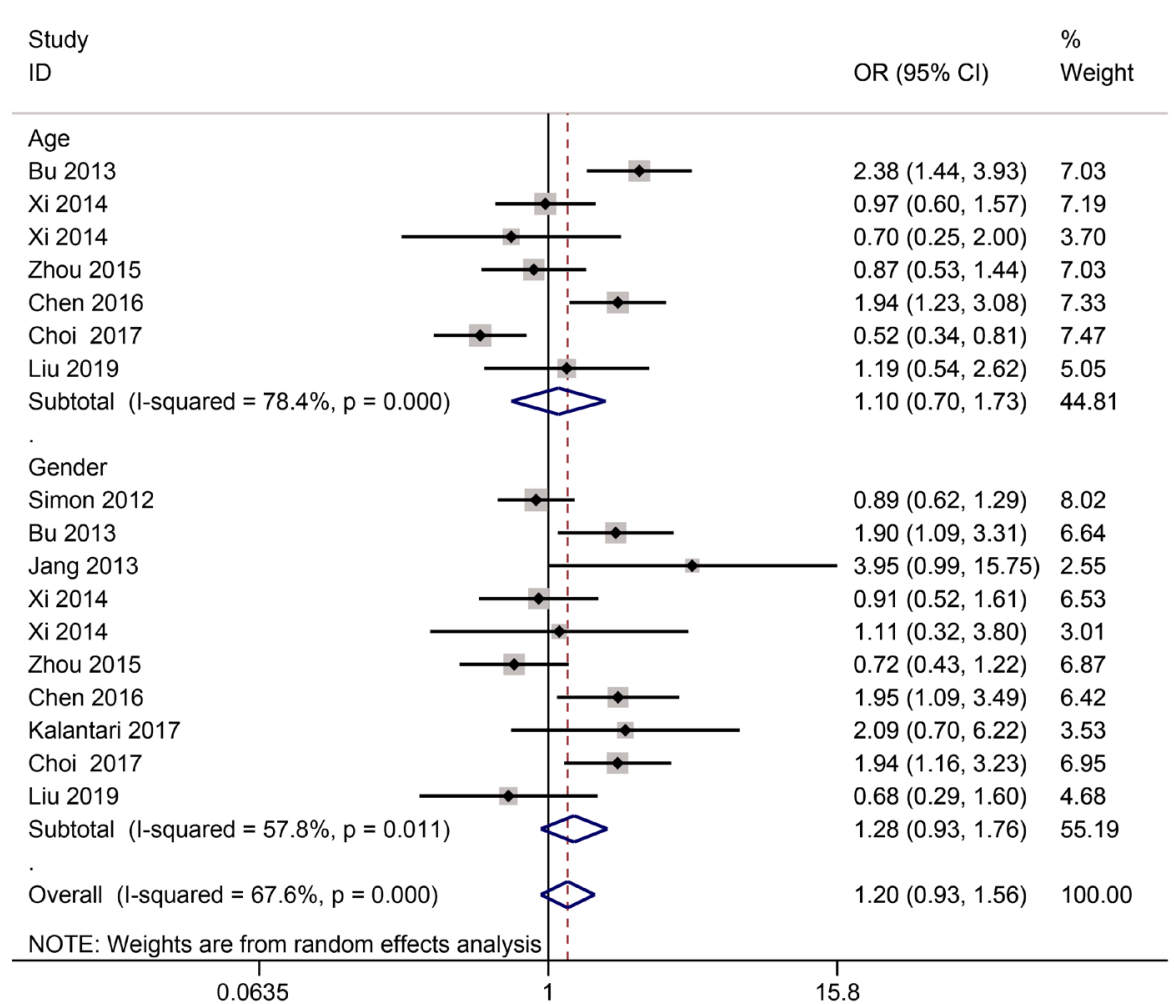

Figure 2. Forest plot for the correlation between LGR5 expression and age ( $\geq 60$ vs. $\leq 60$ years) and gender (male vs. female).

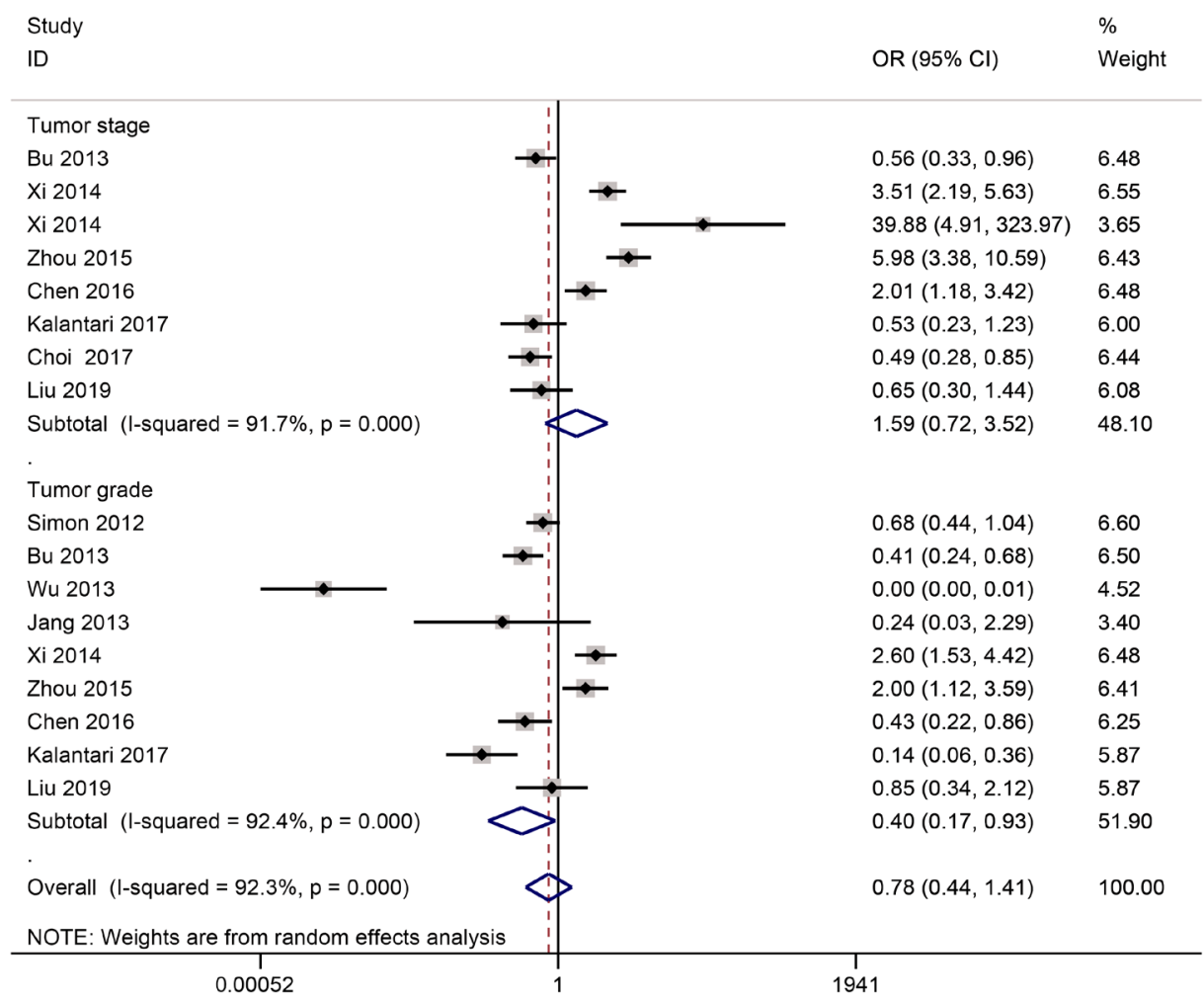

Figure 3. Forest plot for the correlation between LGR5 expression and tumor stage (stage 3-4 vs. stage 1-2) and tumor grade (grade 3-4 vs. grade 1-2). 


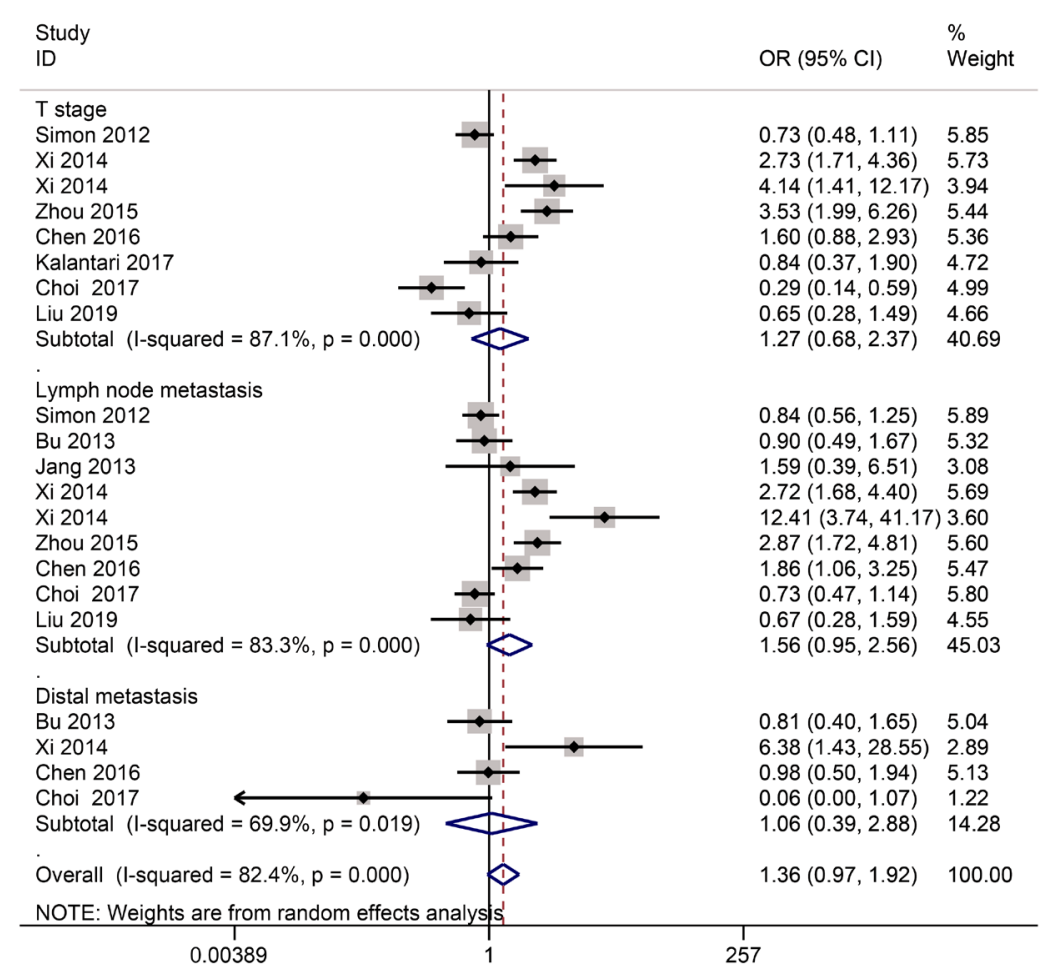

Figure 4. Forest plot for the correlation between LGR5 expression and T stage (T 3-4 vs. T 1-2), and lymph node metastasis (positive vs. negative), and distal metastasis (positive vs. negative).

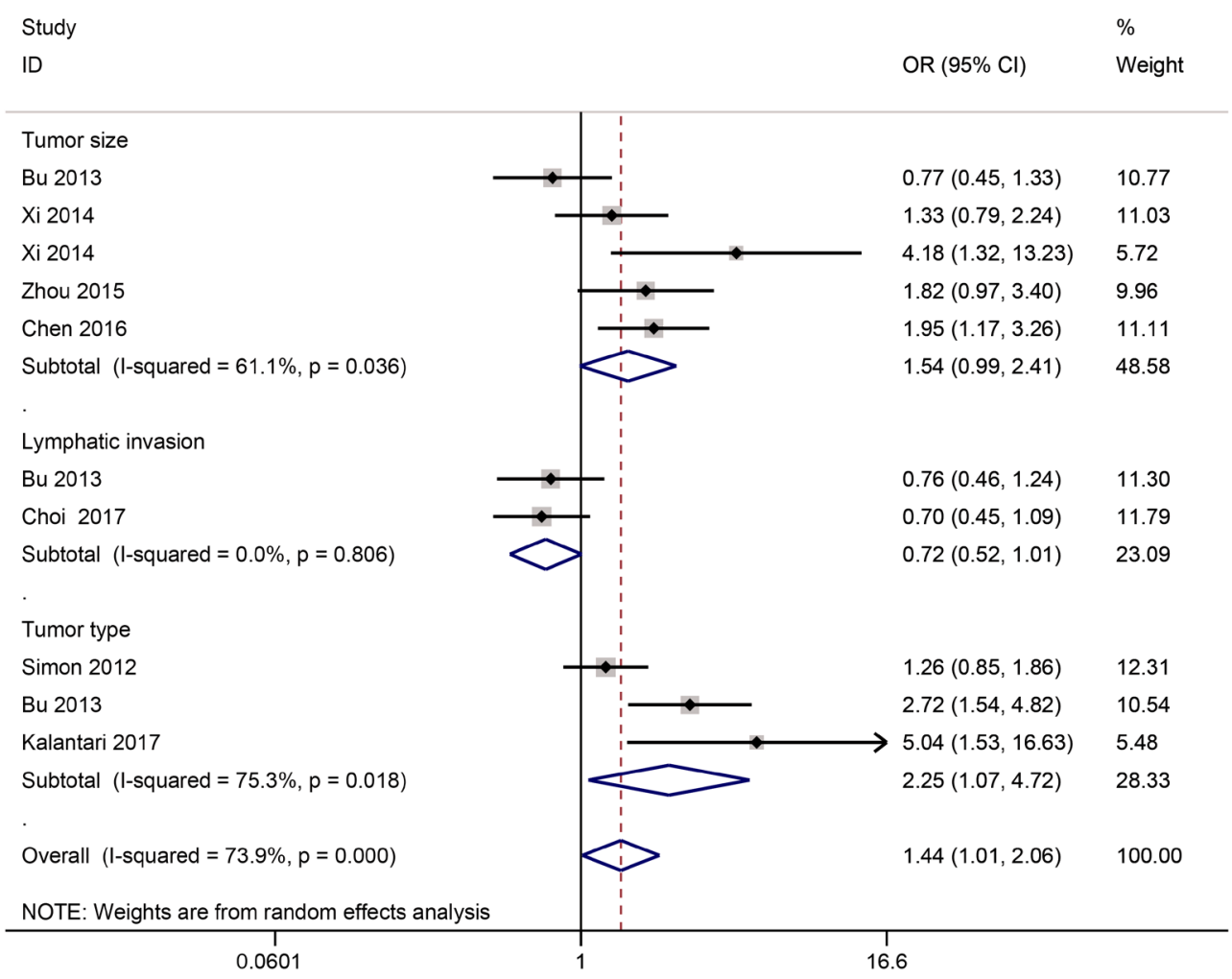

Figure 5. Forest plot for the correlation between LGR5 expression and tumor size ( $\geq 4 \mathrm{vs.} \leq 4 \mathrm{~cm}$ ), lymphatic invasion (positive vs. negative), and tumor type (intestinal vs. diffuse). 
Study

ID

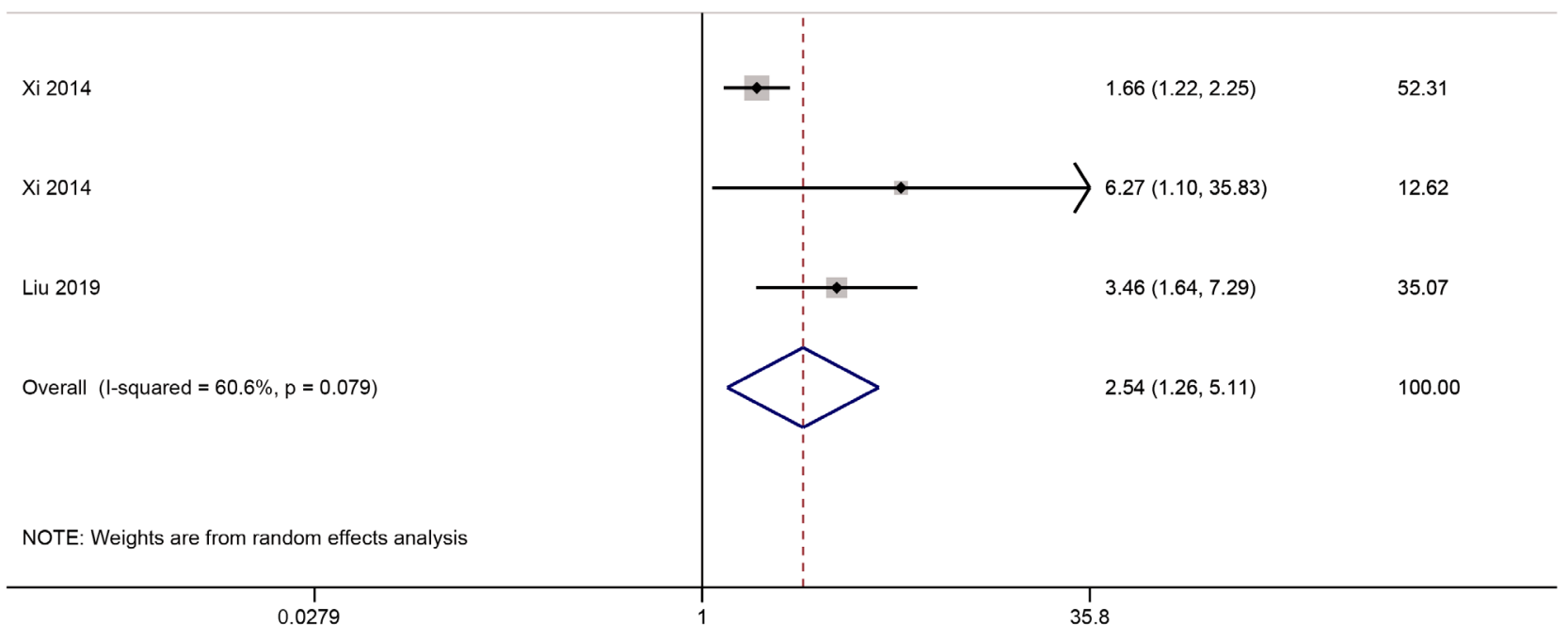

Figure 6. Forest plot for the correlation between LGR5 expression and overall survival (OS).

Heterogeneity analysis. Heterogeneity was detected for significant results between LGR5 and tumor grade and tumor type ( $\mathrm{p}$ of heterogeneity $<0.1$ ). When we removed four studies $[27,29,35,37]$, the re-calculated result was still correlated with tumor grade $(\mathrm{OR}=0.54, \mathrm{p}<0.001)$, with no evidence of heterogeneity $(\mathrm{p}=0.392)$. When we removed this study of Simon 2012 et al. [39], the re-calculated result was still related to tumor type $(\mathrm{OR}=3.05, \mathrm{p}<0.001)$, resulting in no heterogeneity $(\mathrm{p}=0.362)$.

Publication bias. No evidence of publication bias was found between LGR5 and age, gender, tumor stage, tumor grade, $\mathrm{T}$ stage, and lymph node metastasis (all p-values $>0.1$; Supplementary Figure S3).

Further validation from bioinformatics study. 368 patients with GC were analyzed from TCGA data, LGR5 expression was not correlated with age, gender, tumor stage, T-stage, lymph node metastasis, and distal metastasis (all $\mathrm{p}$-values $>0.05$ ), but was higher in grade $1-2$ patients than in grade 3 patients ( $\mathrm{p}=0.035$; Figure 7 ).

Kaplan-Meier survival plot showed that LGR5 expression was associated with worse OS in $876 \mathrm{GC}$ patients $(\mathrm{HR}=1.22$, $95 \% \mathrm{CI}=1.01-1.47, \mathrm{p}=0.04$; Figure 8 ).

\section{Discussion}

Emerging evidence shows that CSCs are associated with tumorigenesis, resistance to chemoradiotherapy, and the prognosis in cancer, suggesting targeting CSCs may repre- sent a promising targeted therapy [40-43]. Cancer stem cell markers such as CD44, CD133, Bmi1, and EpCAM have been identified in GC and may play crucial roles in the prognosis of patients with GC [43-45]. In recent years, LGR5 is discovered as a new functional GSC marker and a common Wnt target gene $[46,47]$. LGR5, as a receptor of GPRs, has been demonstrated to be expressed in some human cancers, such as colorectal cancer [48], lung cancer [49], oral squamous cell carcinoma [50], and hepatocellular carcinoma [51]. Recent studies show that LGR5 is frequently expressed in GC [25-27]. However, the function and role of LGR5 in patients with GC are still largely uncertain. For example, Xi 2014 et al. reported that LGR5 expression was positively correlated with tumor progression of GC [35]. But Kalantari 2017 et al. reported that LGR5 expression was negatively associated with tumor progression of GC [27]. Therefore, in the current study, we systematically investigated the clinicopathological role of LGR5 and its expression on the prognostic effect of patients with GC based on the published articles and bioinformatics data.

The relationships of LGR5 expression with the clinicopathological features of patients with GC were assessed. The previous report showed that LGR5 expression was correlated with tumor stage, including a small population of 710 cases [24]. Our results involving a larger cohort of 1922 GC patients demonstrated no correlation between LGR5 expression and tumor stage, which was also consistent with the previous studies $[25,27]$. No correlation was found between 

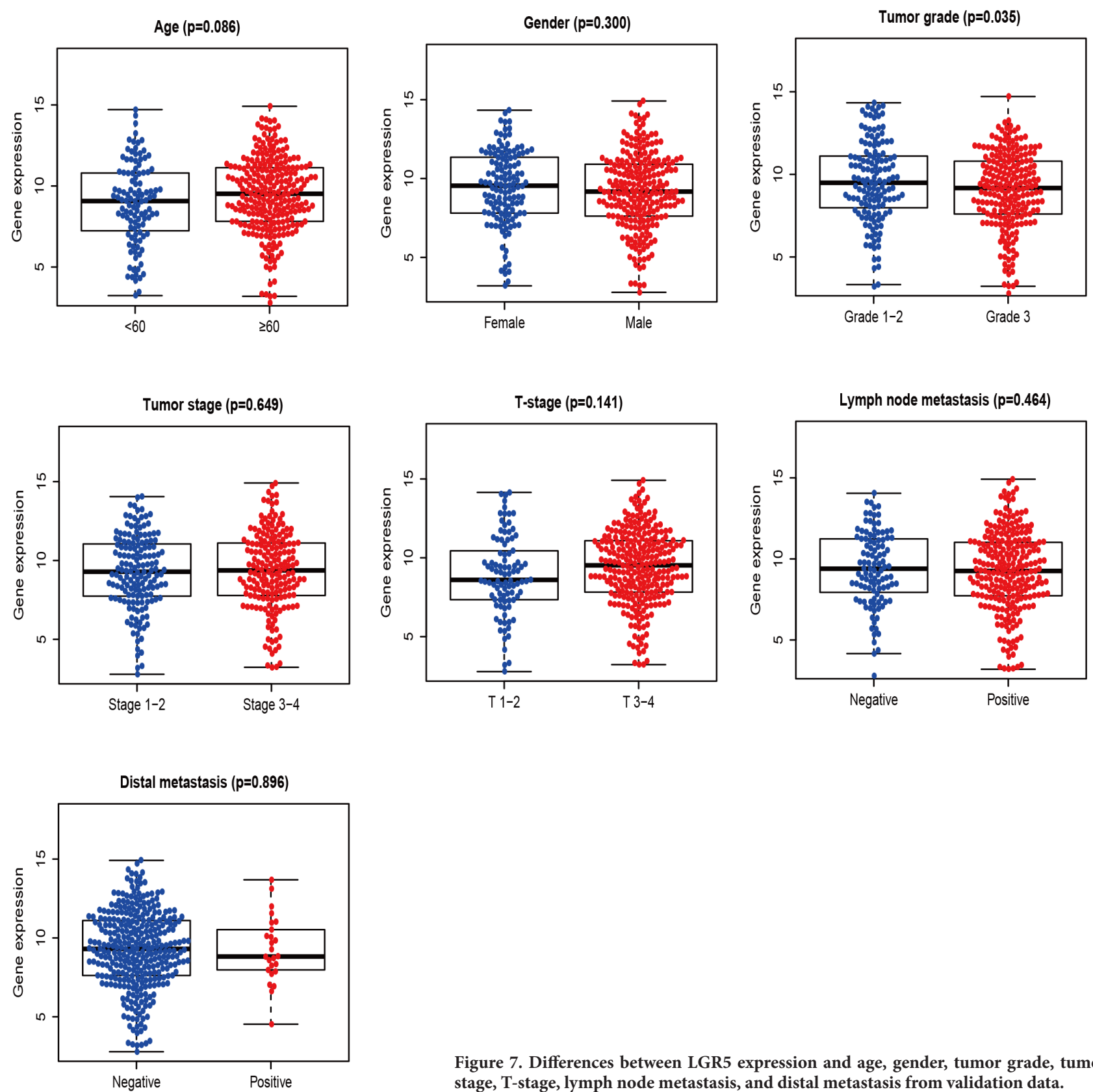

Figure 7. Differences between LGR5 expression and age, gender, tumor grade, tumor stage, T-stage, lymph node metastasis, and distal metastasis from validation data.

LGR5 expression and age and gender, which was in accordance with the studies showed that LGR5 expression was not linked with age $[25,29,34,35]$ and gender $[25,27,29,34-36$, 39]. No relationship was observed between LGR5 expression and theses pathological variables such as T stage, tumor size, lymphatic invasion, lymph node metastasis, and distal metastasis, which were consistent with the previous studies reported that LGR5 expression was not associated with $\mathrm{T}$ stage $[25,27,28,39]$, tumor size $[35,38]$, lymphatic invasion $[26,38]$, lymph node metastasis $[25,26,36,38,39]$, and distal metastasis [28, 38]. LGR5 expression was correlated with tumor type and it was higher in intestinal-type than in diffuse-type, which was consistent with the previous studies $[27,38]$. LGR5 expression was negatively correlated with tumor progression (tumor grade), which was in accordance with the previous studies [27, 28, 37, 38]. Further validation from TCGA data also revealed similar results, LGR 5 expression was not related to age, gender, tumor stage, T-stage, lymph node metastasis, and distal metastasis, and LGR5 expression showed a negative association with tumor grade. 


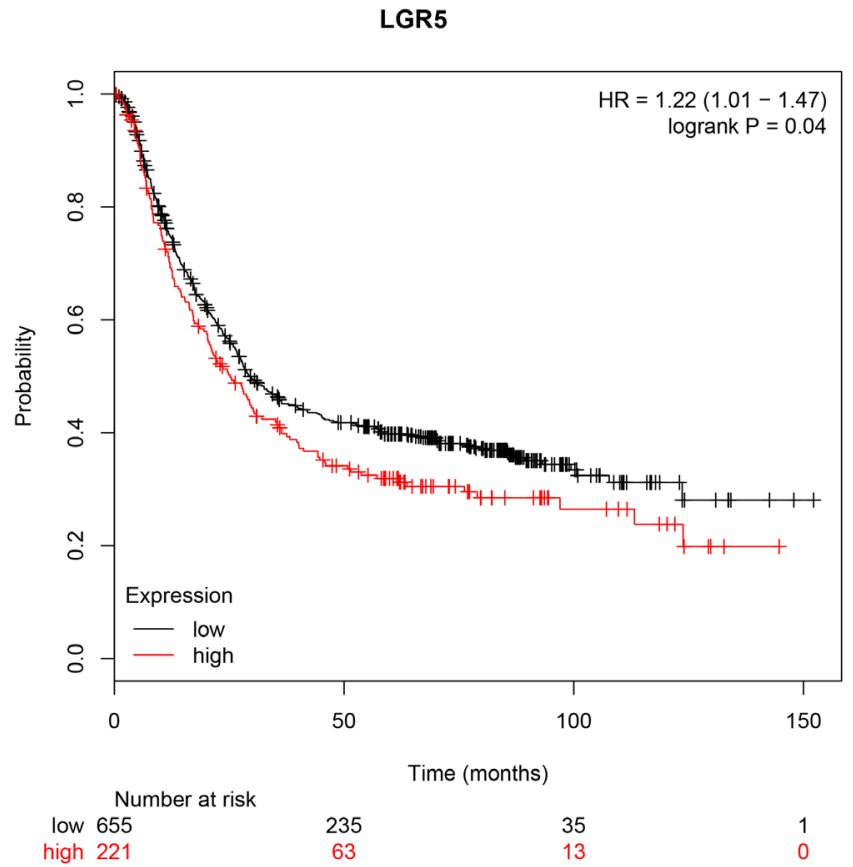

Figure 8. Kaplan-Meier survival plot of LGR5 expression in overall survival (OS) of gastric cancer (GC) from validation data.

LGR5 expression was not associated with cancer-specific survival in 456 cases with GC [26]. The result of the current meta-analysis showed that LGR5 expression was related to worse OS of GC. This finding was consistent with the previous reports $[25,34,35]$. However, we did not find that LGR5 correlated with any other parameters that dictated OS such as tumor size, lymphatic invasion, and metastasis. Possibly due to a small sample size included for OS in this meta-analysis $(n=486)$, it is essential to further validate the prognostic result of LGR5 expression based on larger sample sizes in the future. Further bioinformatics data were used to validate the prognostic role of LGR5 expression and demonstrated that LGR5 expression remained a significant correlation with worse OS of GC.

This meta-analysis presented several limitations. First, nine studies of a total of 11 studies were Asian population; the remaining two studies were Caucasian population, other ethnic groups, such as Africans are lacking. Additional studies are needed in the Caucasian and African populations. Second, the possible reasons for the potential sources of heterogeneity were not very clear based on sensitivity analyses; because the sources of the anti-LGR5 antibody and the definition of cut off values of LGR5 varied among most studies, which may result in the possible heterogeneity. The cut-off values of LGR5 expression should be defined using a uniform standard in the future. Third, the sample sizes on the association of LGR5 with lymphatic invasion and tumor type were not very large. More studies are necessary to further confirm these results.
Although the exact functional or biological mechanisms of LGR5 remains not entirely understood for GC, LGR5 proved to have a valuable prognostic potential. It would be of great interest to verify that LGR5 may become a useful biomarker for predicting OS for GC.

In conclusion, the current meta-analysis demonstrated that LGR5 expression was not correlated with age, gender, tumor stage, $\mathrm{T}$ stage, tumor size, lymphatic invasion, lymph node metastasis, and distal metastasis. LGR5 expression was higher in intestinal-type than in diffuse-type. LGR5 expression was negatively associated with tumor grade, which was consistent with the TCGA validation result. Moreover, LGR5 expression was correlated with a poor prognosis of GC in OS. In the future, additional well-designed prospective studies with larger sample sizes are needed to further validate our findings.

Supplementary information is available in the online version of the paper.

Acknowledgments: We gratefully acknowledge The Cancer Genome Atlas (TCGA).

\section{References}

[1] Bray F, Ferlay J, Soerjomataram I, Siegel RL, Torre LA et al. Global cancer statistics 2018: GLOBOCAN estimates of incidence and mortality worldwide for 36 cancers in 185 countries. CA Cancer J Clin 2020; 70: 313. https://doi. org/10.3322/caac. 21609

[2] CISLO M, FILIP AA, OFFERHAUS GJA, CISEL B, RAWICZ-PRUSZYNSKI $\mathrm{K}$ et al. Distinct molecular subtypes of gastric cancer: from Lauren to molecular pathology. Oncotarget 2018; 9: 19427-19442. https://doi.org/10.18632/oncotarget. 24827

[3] ALSINA M, MOEHLER M, HIERRO C, GUARDENO R, TABERNERO J. Immunotherapy for Gastric Cancer: A Focus on Immune Checkpoints. Target Oncol 2016; 11: 469477. https://doi.org/10.1007/s11523-016-0421-1

[4] CHOI AH, KIM J, CHAO J. Perioperative chemotherapy for resectable gastric cancer: MAGIC and beyond. World J Gastroenterol 2015; 21: 7343-7348. https://doi.org/10.3748/wjg. v21.i24.7343

[5] YANG W, RAUFI A, KLEMPNER SJ. Targeted therapy for gastric cancer: molecular pathways and ongoing investigations. Biochim Biophys Acta 2014; 1846: 232-237. https:// doi.org/10.1016/j.bbcan.2014.05.003

[6] HAN S, HUANG T, WU X, WANG X, LI W et al. Prognostic value of ALDH1 and Nestin in advanced cancer: a systematic meta-analysis with trial sequential analysis. Ther Adv Med Oncol 2019; 11: 1758835919830831. https://doi. org/10.1177/1758835919830831

[7] HAN S, ZONG S, SHI Q, LI H, LIU S et al. Is Ep-CAM Expression a Diagnostic and Prognostic Biomarker for Colorectal Cancer? EBioMedicine 2017; 20: 61-69. https:// doi.org/10.1016/j.ebiom.2017.05.025 
[8] EUN K, HAM SW, KIM H. Cancer stem cell heterogeneity: origin and new perspectives on CSC targeting. BMB Rep 2017 Mar; 5: 117-125. https://doi.org/10.5483/bmbrep.2017.50.3.222

[9] CARNERO A, GARCIA-MAYEA Y, MIR C, LORENTE J, RUBIO IT et al. The cancer stem-cell signaling network and resistance to therapy. Cancer Treat Rev 2016; 49: 25-36. https://doi.org/10.1016/j.ctrv.2016.07.001

[10] ZHANG Y, LI Z, CHEN M, CHEN H, ZHONG Q et al. Identification of a New Eight-Long Noncoding RNA Molecular Signature for Breast Cancer Survival Prediction. DNA Cell Biol 2019; 38: 1529-1539. https://doi.org/10.1089/ dna.2019.5059

[11] ZHENG H, POMYEN Y, HERNANDEZ MO, LI C, LIVAK $\mathrm{F}$ et al. Single-cell analysis reveals cancer stem cell heterogeneity in hepatocellular carcinoma. Hepatology 2018; 68: 127-140. https://doi.org/10.1002/hep.29778

[12] FESSLER E, DIJKGRAAF FE, DE SOUSA EMF, MEDEMA JP. Cancer stem cell dynamics in tumor progression and metastasis: is the microenvironment to blame? Cancer Lett 2013; 341: 97-104. https://doi.org/10.1016/j.canlet.2012.10.015

[13] BECKER L, HUANG Q, MASHIMO H. Immunostaining of Lgr5, an intestinal stem cell marker, in normal and premalignant human gastrointestinal tissue. ScientificWorldJournal 2008; 8: 1168-1176. https://doi.org/10.1100/tsw.2008.148

[14] HSU SY, LIANG SG, HSUEH AJ. Characterization of two LGR genes homologous to gonadotropin and thyrotropin receptors with extracellular leucine-rich repeats and a $G$ protein-coupled, seven-transmembrane region. Mol Endocrinol 1998; 12: 1830-1845. https://doi.org/10.1210/ mend.12.12.0211

[15] DE SOUSA E MELO F, KURTOVA AV, HARNOSS JM, KLJAVIN N, HOECK JD et al. A distinct role for Lgr5(+) stem cells in primary and metastatic colon cancer. Nature 2017; 543: 676-680. https://doi.org/10.1038/nature21713

[16] LEUNG C, TAN SH, BARKER N. Recent Advances in Lgr5(+) Stem Cell Research. Trends Cell Biol 2018; 28: 380391. https://doi.org/10.1016/j.tcb.2018.01.010

[17] BASU S, HAASE G, BEN-ZE'EV A. Wnt signaling in cancer stem cells and colon cancer metastasis. F1000Res 2016; 5: F1000 Faculty Rev-699. https://doi.org/10.12688/f1000research.7579.1

[18] SIGAL M, REINES MDM, MULLERKE S, FISCHER C, KAPALCZYNSKA $M$ et al. R-spondin-3 induces secretory, antimicrobial Lgr5(+) cells in the stomach. Nat Cell Biol 2019; 21: 812-823. https://doi.org/10.1038/s41556-0190339-9

[19] EFFENDI K, YAMAZAKI K, FUKUMA M, SAKAMOTO M. Overexpression of Leucine-Rich Repeat-Containing G Protein-Coupled Receptor 5 (LGR5) Represents a Typical Wnt/beta-Catenin Pathway-Activated Hepatocellular Carcinoma. Liver Cancer 2014; 3: 451-457. https://doi. org/10.1159/000343873

[20] TANESE K, FUKUMA M, YAMADA T, MORI T, YOSHIKAWA T et al. G-protein-coupled receptor GPR49 is up-regulated in basal cell carcinoma and promotes cell proliferation and tumor formation. Am J Pathol 2008; 173: 835-843. https://doi.org/10.2353/ajpath.2008.071091
[21] HAN Y, XUE X, JIANG M, GUO X, LI P et al. LGR5, a relevant marker of cancer stem cells, indicates a poor prognosis in colorectal cancer patients: a meta-analysis. Clin Res Hepatol Gastroenterol 2015; 39: 267-273. https://doi. org/10.1016/j.clinre.2014.07.008

[22] HSU HC, LIU YS, TSENG KC, TAN BC, CHEN SJ et al. LGR5 regulates survival through mitochondria-mediated apoptosis and by targeting the Wnt/beta-catenin signaling pathway in colorectal cancer cells. Cell Signal 2014; 26: 2333-2342. https://doi.org/10.1016/j.cellsig.2014.07.004

[23] LI XB, YANG G, ZHU L, TANG YL, ZHANG C et al. Gastric Lgr5(+) stem cells are the cellular origin of invasive intestinal-type gastric cancer in mice. Cell Res 2016; 26: 838-849. https://doi.org/10.1038/cr.2016.47

[24] HUANG T, QIU X, XIAO J, WANG Q, WANG Y et al. The prognostic role of Leucine-rich repeat-containing G-proteincoupled receptor 5 in gastric cancer: A systematic review with meta-analysis. Clin Res Hepatol Gastroenterol 2016; 40: 246-253. https://doi.org/10.1016/j.clinre.2015.07.009

[25] LIU XS, LIN XK, MEI Y, AHMAD S, YAN CX et al. Regulatory T Cells Promote Overexpression of Lgr5 on Gastric Cancer Cells via TGF-beta1 and Confer Poor Prognosis in Gastric Cancer. Front Immunol 2019; 10: 1741. https://doi. org/10.3389/fimmu.2019.01741

[26] CHOI Y, PARK J, KO YS, KIM Y, PYO JS et al. FOXO1 reduces tumorsphere formation capacity and has crosstalk with LGR5 signaling in gastric cancer cells. Biochem Biophys Res Commun 2017; 493: 1349-1355. https://doi.org/10.1016/j. bbrc.2017.09.163

[27] KALANTARI E, ASADI LARI MH, ROUDI R, KOROURIAN A, MADJD Z. Lgr5High/DCLK1High phenotype is more common in early stage and intestinal subtypes of gastric carcinomas. Cancer Biomark 2017; 20: 563-573. https:// doi.org/10.3233/CBM-170383

[28] CHEN XL, CHEN XZ, WANG YG, HE D, LU ZH et al. Clinical significance of putative markers of cancer stem cells in gastric cancer: A retrospective cohort study. Oncotarget 2016; 7: 62049-62069. https://doi.org/10.18632/oncotarget. 11384

[29] ZHOU L, YU L, FENG ZZ, GONG XM, CHENG ZN et al. Aberrant Expression of Markers of Cancer Stem Cells in Gastric Adenocarcinoma and their Relationship to Vasculogenic Mimicry. Asian Pac J Cancer Prev 2015; 16: 41774183. https://doi.org/10.7314/apjcp.2015.16.10.4177

[30] MOHER D, LIBERATI A, TETZLAFF J, ALTMAN DG, GROUP P. Preferred reporting items for systematic reviews and meta-analyses: the PRISMA statement. PLoS Med 2009; 6: e1000097. https://doi.org/10.1371/journal.pmed.1000097

[31] ZINTZARAS E, IOANNIDIS JP. HEGESMA: genome search meta-analysis and heterogeneity testing. Bioinformatics 2005; 21: 3672-3673. https://doi.org/10.1093/bioinformatics/bti536

[32] EGGER M, DAVEY SMITH G, SCHNEIDER M, MINDER C. Bias in meta-analysis detected by a simple, graphical test. BMJ 1997; 315: 629-634. https://doi.org/10.1136/ bmj.315.7109.629 
[33] SZASZ AM, LANCZKY A, NAGY A, FORSTER S, HARK $\mathrm{K}$ et al. Cross-validation of survival associated biomarkers in gastric cancer using transcriptomic data of 1,065 patients. Oncotarget 2016; 7: 49322-49333. https://doi.org/10.18632/ oncotarget.10337

[34] XI HQ, CUI JX, SHEN WS, WU XS, BIAN SB et al. Increased expression of Lgr5 is associated with chemotherapy resistance in human gastric cancer. Oncol Rep 2014; 32: 181188. https://doi.org/10.3892/or.2014.3207

[35] XI HQ, CAI AZ, WU XS, CUI JX, SHEN WS et al. Leucinerich repeat-containing G-protein-coupled receptor 5 is associated with invasion, metastasis, and could be a potential therapeutic target in human gastric cancer. Br J Cancer 2014; 110: 2011-2020. https://doi.org/10.1038/bjc.2014.112

[36] JANG BG, LEE BL, KIM WH. Distribution of LGR5+ cells and associated implications during the early stage of gastric tumorigenesis. PLoS One 2013; 8: e82390. https://doi. org/10.1371/journal.pone.0082390

[37] WU C, XIE Y, GAO F, WANG Y, GUO Y et al. Lgr5 expression as stem cell marker in human gastric gland and its relatedness with other putative cancer stem cell markers. Gene 2013; 525: 18-25. https://doi.org/10.1016/j.gene.2013.04.067

[38] BU Z, ZHENG Z, ZHANG L, LI Z, SUN Y et al. LGR5 is a promising biomarker for patients with stage I and II gastric cancer. Chin J Cancer Res 2013; 25: 79-89. https://doi. org/10.3978/j.issn.1000-9604.2013.01.07

[39] SIMON E, PETKE D, BOGER C, BEHRENS HM, WARNEKE $\mathrm{V}$ et al. The spatial distribution of LGR5+ cells correlates with gastric cancer progression. PLoS One 2012; 7: e35486. https://doi.org/10.1371/journal.pone.0035486

[40] HAN S, HUANG T, LI W, WANG X, WU X et al. Prognostic Value of CD44 and Its Isoforms in Advanced Cancer: A Systematic Meta-Analysis With Trial Sequential Analysis. Front Oncol 2019; 9: 39. https://doi.org/10.3389/fonc.2019.00039

[41] PAN Y, MA S, CAO K, ZHOU S, ZHAO A et al. Therapeutic approaches targeting cancer stem cells. J Cancer Res Ther 2018; 4: 1469-1475. https://doi.org/10.4103/jcrt. JCRT_976_17

[42] MEDEMA JP. Targeting the Colorectal Cancer Stem Cell. N Engl J Med 2017; 377: 888-890. https://doi.org/10.1056/ NEJMcibr 1706541
[43] LU L, WU M, SUN L, LI W, FU W et al. Clinicopathologi$\mathrm{cal}$ and prognostic significance of cancer stem cell markers CD44 and CD133 in patients with gastric cancer: A comprehensive meta-analysis with 4729 patients involved. Medicine (Baltimore) 2016; 95: e5163. https://doi.org/10.1097/ MD.0000000000005163

[44] DAI M, YUAN F, FU C, SHEN G, HU S et al. Relationship between epithelial cell adhesion molecule (EpCAM) overexpression and gastric cancer patients: A systematic review and meta-analysis. PLoS One 2017; 12: e0175357. https:// doi.org/10.1371/journal.pone.0175357

[45] YUAN B, ZHAO H, XUE X, ZHOU J, WANG X et al. Prognostic Value and Clinicopathological Differences of Bmil in Gastric Cancer: A Meta-analysis. Anticancer Agents Med Chem 2016; 16: 407-413. https://doi.org/10.2174/18715206 15666150507120801

[46] DE LAU W, PENG WC, GROS P, CLEVERS H. The R-spondin/Lgr5/Rnf43 module: regulator of Wnt signal strength. Genes Dev 2014; 28: 305-316. https://doi.org/10.1101/ $\operatorname{gad} .235473 .113$

[47] SATO T, VAN ES JH, SNIPPERT HJ, STANGE DE, VRIES RG et al. Paneth cells constitute the niche for Lgr5 stem cells in intestinal crypts. Nature 2011; 469: 415-418. https://doi. org/10.1038/nature09637

[48] JIANG Y, LI W, HE X, ZHANG H, JIANG F et al. Lgr5 expression is a valuable prognostic factor for colorectal cancer: evidence from a meta-analysis. BMC Cancer 2015; 15: 948. https://doi.org/10.1186/s12885-015-1985-3

[49] Gautam AK, Wang C, Zeng J, Wang J, Lu J et al. Expression and clinical significance of SALL4 and LGR5 in patients with lung cancer. Oncol Lett 2015; 10: 3629-3634. https://doi. org/10.3892/ol.2015.3772

[50] DALLEY AJ, ABDUL MAJEED AA, PITTY LP, MAJOR AG, FARAH CS. LGR5 expression in oral epithelial dysplasia and oral squamous cell carcinoma. Oral Surg Oral Med Oral Pathol Oral Radiol 2015; 119: 436-40.e1. https://doi. org/10.1016/j.oooo.2014.11.014

[51] MA Z, GUO D, WANG Q, LIU P, XIAO Y et al. Lgr5-mediated p53 Repression through PDCD5 leads to doxorubicin resistance in Hepatocellular Carcinoma. Theranostics 2019; 9: 2967-2983. https://doi.org/10.7150/thno.30562 
https://doi.org/10.4149/neo_2021_200714N726

\section{The clinical and prognostic significance of LGR5 in GC: A meta-analysis of IHC assay and bioinformatics analysis}

Fei GUO ${ }^{1}$, Tao YANG ${ }^{1}$, Rende GUO 1 , Yu WANG ${ }^{2, *}$

\section{Supplementary Information}
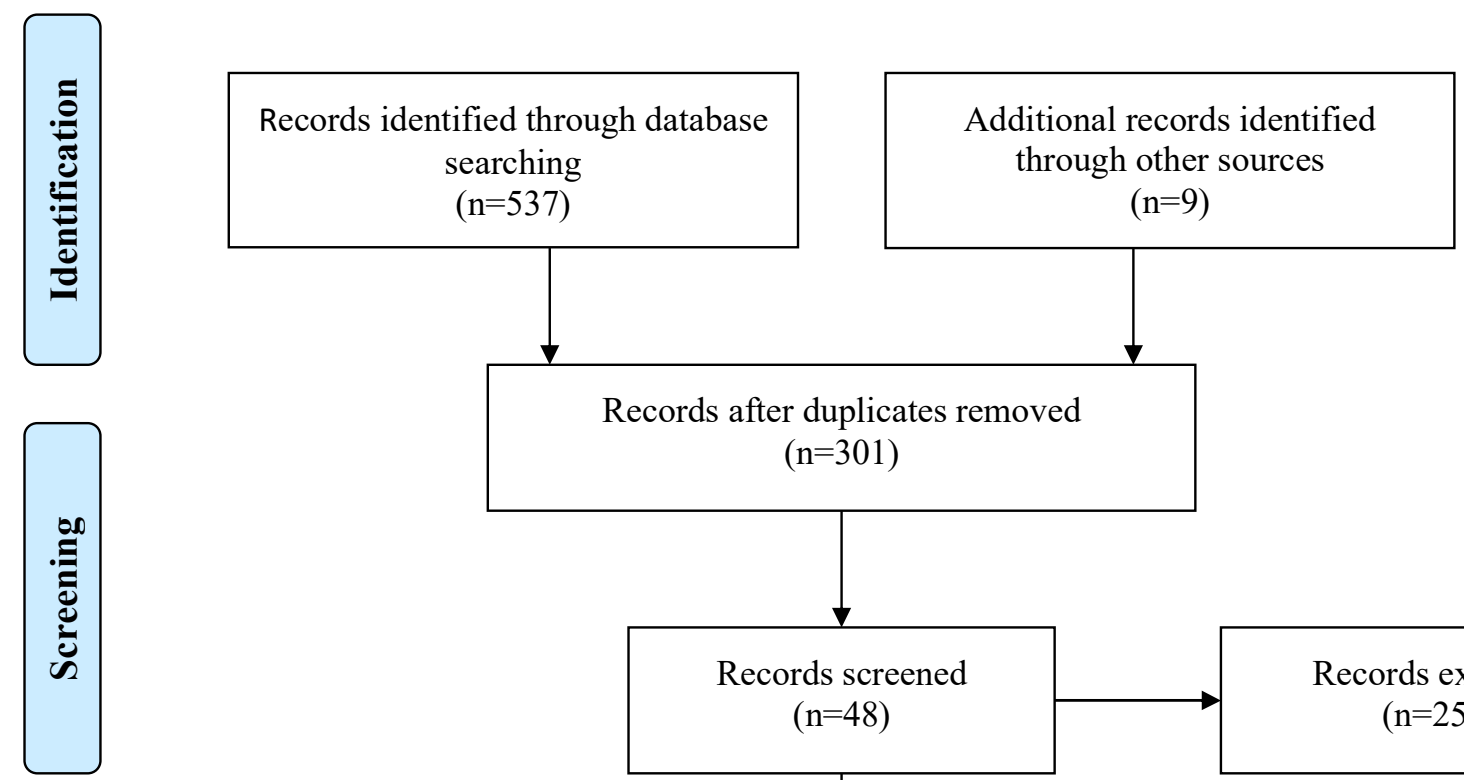

Records after duplicates removed
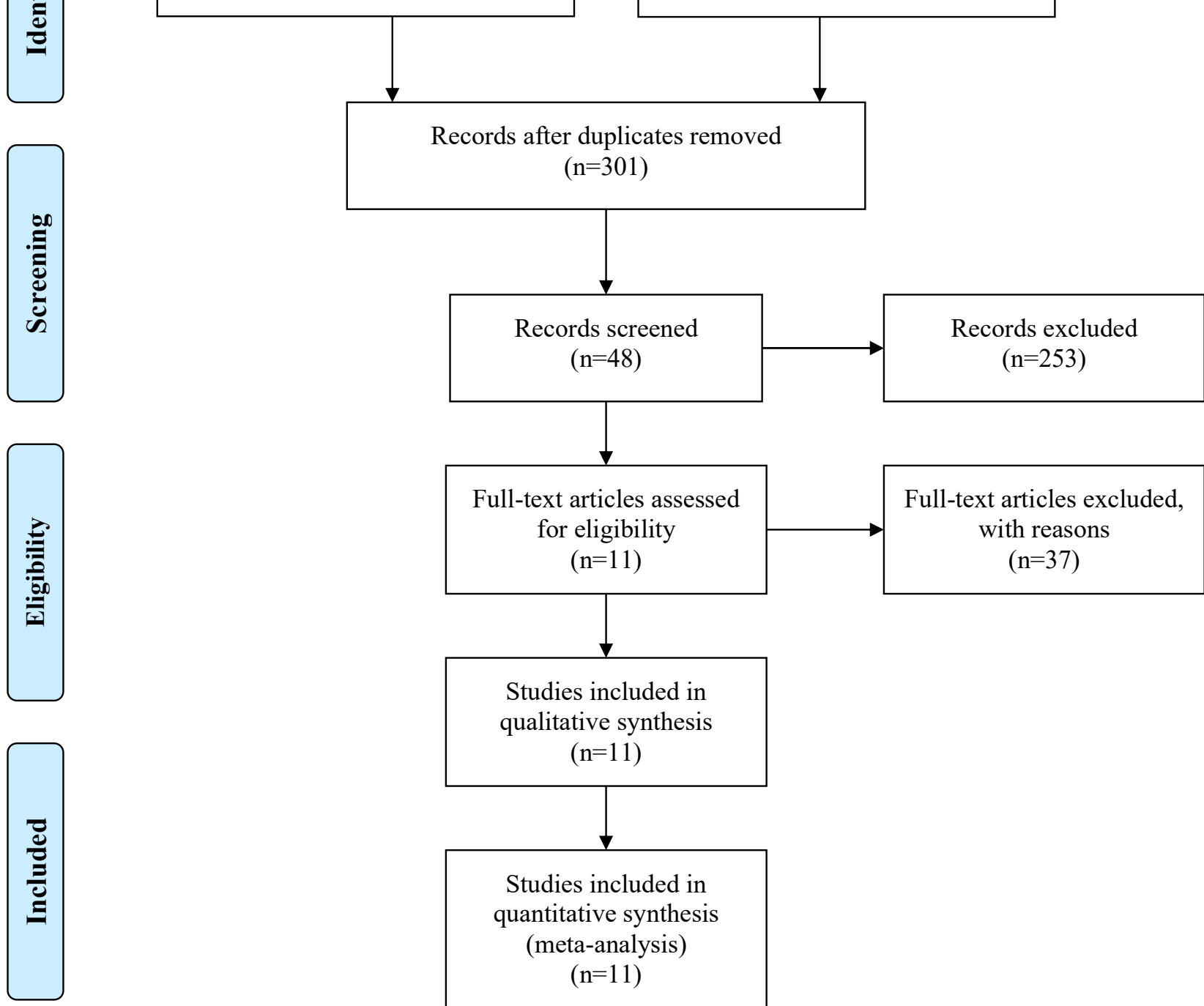

Studies included in qualitative synthesis $(\mathrm{n}=11)$

Studies included in quantitative synthesis

(meta-analysis)

$$
(\mathrm{n}=11)
$$




\begin{tabular}{|c|c|c|c|c|c|c|c|c|c|c|c|c|c|}
\hline \multirow{2}{*}{\multicolumn{2}{|c|}{ 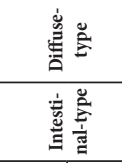 }} & 覀吾 & $\begin{array}{l}\frac{\infty}{2} \\
\frac{7}{3} \\
\frac{3}{=}\end{array}$ & 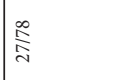 & & & & & & & $\frac{\partial}{F}$ & & \\
\hline & & 㱏尊 & 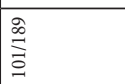 & 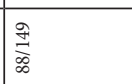 & & & & & & & $\frac{2}{\frac{2}{7}}$ & & \\
\hline \multirow{2}{*}{ 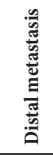 } & 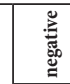 & 手部 & & 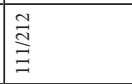 & & & 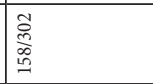 & & & 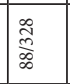 & & 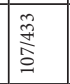 & \\
\hline & 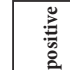 & 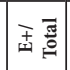 & & 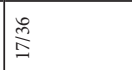 & & & 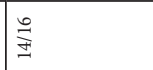 & & & $\frac{\partial}{\partial}$ & & $\cong$ & \\
\hline \multirow{2}{*}{ 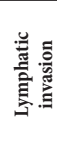 } & 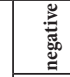 & 毒要 & & 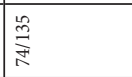 & & & & & & & & 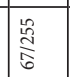 & \\
\hline & 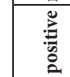 & 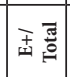 & & $\overbrace{i=1}$ & & & & & & & & 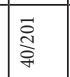 & \\
\hline \multirow{2}{*}{ 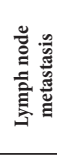 } & 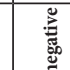 & 㽭恶 & 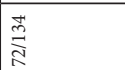 & 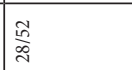 & & 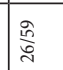 & 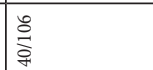 & $\frac{\pi}{n}$ & $\frac{7}{5}$ & $\frac{\partial}{\partial}$ & & 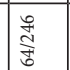 & $\mid \begin{array}{l}\infty \\
\infty \\
\infty\end{array}$ \\
\hline & 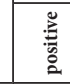 & 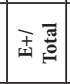 & 望 & 骂 & & के & $\begin{array}{l}\text { Iี } \\
\text { त्र } \\
\end{array}$ & 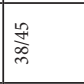 & స్ & 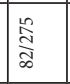 & & \begin{tabular}{|l|}
$\frac{2}{3}$ \\
$\frac{7}{7}$ \\
\end{tabular} & 离 \\
\hline \multirow{2}{*}{ 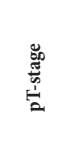 } & $I$ & 声吾 & 荥 & & & & $\frac{\bar{a}}{\sqrt{7}}$ & 管 & 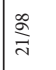 & 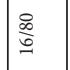 & $\frac{z}{z}$ & 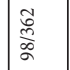 & 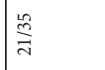 \\
\hline & $I$ & 毒要 & 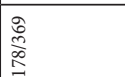 & & & & 总 & $\mid \frac{0}{2}$ & 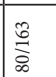 & 空 & $\frac{\pi}{\frac{\pi}{n}}$ & 苛 & $\mid \frac{6}{0}$ \\
\hline \multirow{2}{*}{ 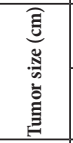 } & $\overrightarrow{\mathrm{v}}$ & 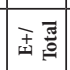 & & $\mid$\begin{tabular}{|l|l}
$\infty$ \\
$\frac{\infty}{6}$ \\
0
\end{tabular} & & & 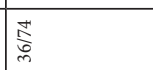 & 츤 & $\frac{8}{5}$ & 蕉 & & & \\
\hline & $\vec{\lambda}$ & 畫吾 & & \begin{tabular}{|l|}
8 \\
\\
离
\end{tabular} & & & 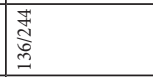 & 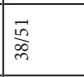 & 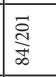 & 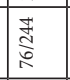 & & & \\
\hline \multirow{2}{*}{ हूँ } & $I$ & 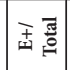 & $\underset{0}{\stackrel{2}{*}}$ & $\stackrel{\text { ng }}{=}$ & $\frac{2}{2}$ & 商 & 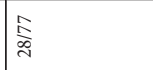 & & हิ๊ & $\begin{array}{l}\text { 章 } \\
\frac{1}{1}\end{array}$ & $\frac{\text { s/ }}{2}$ & & $\frac{2}{9}$ \\
\hline & $I$ & 㶣焉 & 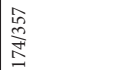 & 趈 & $\frac{0}{1}$ & $\stackrel{\text { I }}{=}$ & 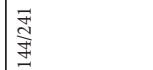 & & $\frac{\mathrm{o}}{\mathrm{m}}$ & 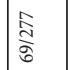 & $\begin{array}{l}\sqrt{5} \\
\frac{2}{2}\end{array}$ & & $\mid \frac{2}{5}$ \\
\hline \multirow{2}{*}{$\begin{array}{l}\text { 总 } \\
\text { 总 }\end{array}$} & $I$ & 罀总 & & 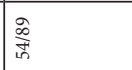 & & & 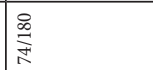 & 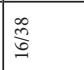 & $\begin{array}{l}\text { ป̃ } \\
\text { ন্ন }\end{array}$ & 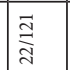 & 啇 & 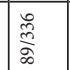 & $\frac{10}{2}$ \\
\hline & I & 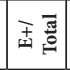 & & 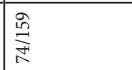 & & & 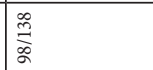 & $\frac{d}{2}$ & 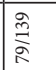 & 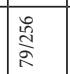 & 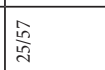 & 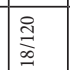 & 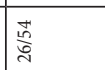 \\
\hline & 要 & 弁吾 & 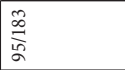 & \begin{tabular}{|l}
$\frac{9}{2}$ \\
$\frac{a}{4}$
\end{tabular} & & $\stackrel{\vec{m}}{m}$ & 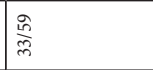 & $\vec{\partial}$ & $\begin{array}{l}\frac{\alpha}{2} \\
\text { ô }\end{array}$ & 总 & 17 & 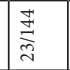 & $\frac{\tilde{D}}{\partial}$ \\
\hline \multicolumn{2}{|c|}{$\frac{\pi}{\frac{\pi}{2}}$} & 霓吾 & 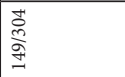 & 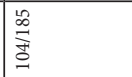 & & \begin{tabular}{|l} 
苦 \\
s. \\
in
\end{tabular} & 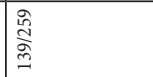 & 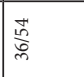 & 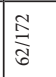 & 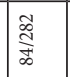 & 点 & 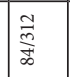 & 兽 \\
\hline \multicolumn{2}{|c|}{$\stackrel{S}{S}$} & 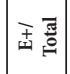 & & בิ & & & 苂 & $\frac{\text { fo }}{m}$ & $\underset{7}{\stackrel{7}{7}}$ & 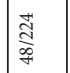 & & $\overline{\mathrm{z}}$ & 莫 \\
\hline \multicolumn{2}{|c|}{ 足 } & 昰焉 & & $\underset{\substack{0 \\
\infty \\
\infty}}{\infty}$ & & & 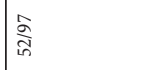 & $\frac{\pi}{\nexists}$ & 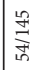 & 急 & & 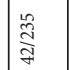 & $\mid$ \\
\hline \multicolumn{2}{|c|}{ 岛 } & 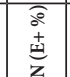 & 票高 & 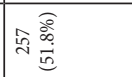 & 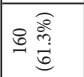 & 舟事 & $\frac{\infty}{m} \frac{\bar{g}}{0.0}$ & \& & 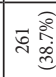 & 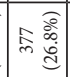 & F。 & 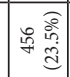 & 施 \\
\hline \multicolumn{3}{|c|}{ 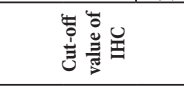 } & 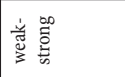 & 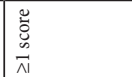 & 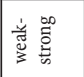 & $\frac{\pi}{z}$ & 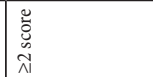 & 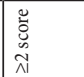 & 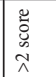 & 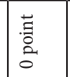 & 总䒿 & $\frac{\pi}{z}$ & 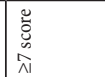 \\
\hline \multicolumn{3}{|c|}{ 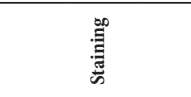 } & 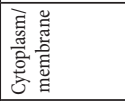 & 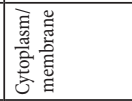 & $\frac{\pi}{z}$ & $\bar{z}$ & 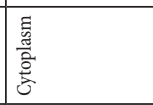 & 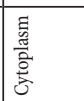 & 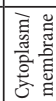 & \begin{tabular}{|l|} 
量 \\
息 \\
总
\end{tabular} & 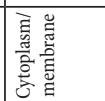 & 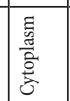 & $\frac{\pi}{z}$ \\
\hline \multicolumn{3}{|c|}{ 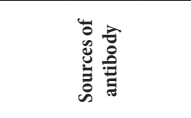 } & 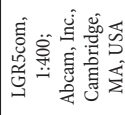 & 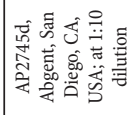 & 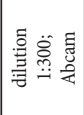 & $\frac{\pi}{z}$ & 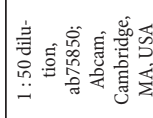 & 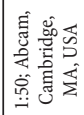 & 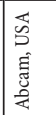 & 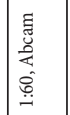 & 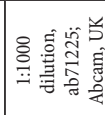 & 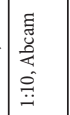 & 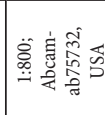 \\
\hline \multicolumn{3}{|c|}{$\begin{array}{l}\text { 高 } \\
\text { 竞 }\end{array}$} & 尊 & 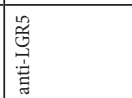 & 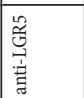 & 咆 & 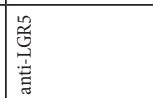 & 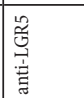 & 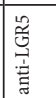 & 哭 & 总 & 总 & 部 \\
\hline \multicolumn{3}{|c|}{ 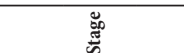 } & $\frac{\pi}{\pi}$ & $I$ & $\frac{\pi}{z}$ & $\frac{\pi}{z}$ & $I$ & 9 & \pm & $I$ & $I$ & $I$ & 9 \\
\hline \multicolumn{3}{|c|}{$x^{q}$} & $\infty$ & 5 & 部 & $\frac{\pi}{\mathrm{z}}$ & 응 & 8 & 8 & $\frac{\pi}{z}$ & 8 & $\bar{z}$ & 8 \\
\hline \multicolumn{3}{|c|}{ 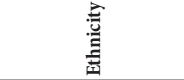 } & 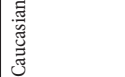 & 喜 & 喜 & 喜 & 喜 & 喜 & 毫 & 竞 & 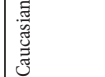 & 辤 & $\frac{5}{\frac{5}{9}}$ \\
\hline \multicolumn{3}{|c|}{ 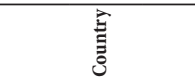 } & 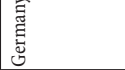 & 意 & | & 离 & 总 & 鄫 & 曾 & 总 & 롭 & 总 & 砶 \\
\hline \multicolumn{3}{|c|}{ 营总 } & 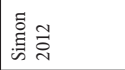 & Im & $\xi \tilde{\sigma}^{m}$ & 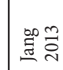 & $\approx \stackrel{\Delta}{*}$ & 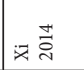 & 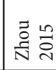 & 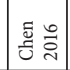 & 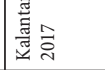 & 홍 & छ \\
\hline
\end{tabular}




\begin{tabular}{|c|c|c|c|}
\hline Section/Topic & $\#$ & Checklist Item & $\begin{array}{l}\text { Reported } \\
\text { on Page \# }\end{array}$ \\
\hline \multicolumn{4}{|l|}{ TITLE } \\
\hline Title & 1 & Identify the report as a systematic review, meta-analysis, or both. & 1 \\
\hline \multicolumn{4}{|l|}{ ABSTRACT } \\
\hline Structured summary & 2 & $\begin{array}{l}\text { Provide a structured summary including, as applicable: background; objectives; data sources; study eligibility criteria, } \\
\text { participants, and interventions; study appraisal and synthesis methods; results; limitations; conclusions and } \\
\text { implications of key findings; systematic review registration number. }\end{array}$ & 2 \\
\hline \multicolumn{4}{|l|}{ INTRODUCTION } \\
\hline Rationale & 3 & Describe the rationale for the review in the context of what is already known. & $3-4$ \\
\hline Objectives & 4 & $\begin{array}{l}\text { Provide an explicit statement of questions being addressed with reference to participants, interventions, comparisons, } \\
\text { outcomes, and study design (PICOS). }\end{array}$ & 4 \\
\hline \multicolumn{4}{|l|}{ METHODS } \\
\hline Protocol and registration & 5 & $\begin{array}{l}\text { Indicate if a review protocol exists, if and where it can be accessed (e.g., Web address), and, if available, provide } \\
\text { registration information including registration number. }\end{array}$ & 4 \\
\hline Eligibility criteria & 6 & $\begin{array}{l}\text { Specify study characteristics (e.g., PICOS, length of follow-up) and report characteristics (e.g., years considered, } \\
\text { language, publication status) used as criteria for eligibility, giving rationale. }\end{array}$ & $4-5$ \\
\hline Information sources & 7 & $\begin{array}{l}\text { Describe all information sources (e.g., databases with dates of coverage, contact with study authors to identify } \\
\text { additional studies) in the search and date last searched. }\end{array}$ & 4 \\
\hline Search & 8 & $\begin{array}{l}\text { Present full electronic search strategy for at least one database, including any limits used, such that it could be } \\
\text { repeated. }\end{array}$ & 4 \\
\hline Study selection & 9 & $\begin{array}{l}\text { State the process for selecting studies (i.e., screening, eligibility, included in systematic review, and, if applicable, } \\
\text { included in the meta-analysis). }\end{array}$ & 5 \\
\hline Data collection process & 10 & $\begin{array}{l}\text { Describe method of data extraction from reports (e.g., piloted forms, independently, in duplicate) and any processes } \\
\text { for obtaining and confirming data from investigators. }\end{array}$ & 5 \\
\hline Data items & 11 & $\begin{array}{l}\text { List and define all variables for which data were sought (e.g., PICOS, funding sources) and any assumptions and } \\
\text { simplifications made. }\end{array}$ & 5 \\
\hline $\begin{array}{l}\text { Risk of bias in individual } \\
\text { studies }\end{array}$ & 12 & $\begin{array}{l}\text { Describe methods used for assessing risk of bias of individual studies (including specification of whether this was } \\
\text { done at the study or outcome level), and how this information is to be used in any data synthesis. }\end{array}$ & $5-6$ \\
\hline Summary measures & 13 & State the principal summary measures (e.g., risk ratio, difference in means). & 5 \\
\hline Synthesis of results & 14 & $\begin{array}{l}\text { Describe the methods of handling data and combining results of studies, if done, including measures of consistency } \\
\left(e . g .,\left.\right|^{2}\right) \text { for each meta-analysis. }\end{array}$ & 5 \\
\hline Risk of bias across studies & 15 & $\begin{array}{l}\text { Specify any assessment of risk of bias that may affect the cumulative evidence (e.g., publication bias, selective } \\
\text { reporting within studies). }\end{array}$ & 5 \\
\hline Additional analyses & 16 & $\begin{array}{l}\text { Describe methods of additional analyses (e.g., sensitivity or subgroup analyses, meta-regression), if done, indicating } \\
\text { which were pre-specified. }\end{array}$ & 5 \\
\hline \multicolumn{4}{|l|}{ RESULTS } \\
\hline Study selection & 17 & $\begin{array}{l}\text { Give numbers of studies screened, assessed for eligibility, and included in the review, with reasons for exclusions at } \\
\text { each stage, ideally with a flow diagram. }\end{array}$ & 6 \\
\hline Study characteristics & 18 & $\begin{array}{l}\text { For each study, present characteristics for which data were extracted (e.g., study size, PICOS, follow-up period) and } \\
\text { provide the citations. }\end{array}$ & 6 \\
\hline Risk of bias within studies & 19 & Present data on risk of bias of each study and, if available, any outcome level assessment (see item 12). & 8 \\
\hline Results of individual studies & 20 & $\begin{array}{l}\text { For all outcomes considered (benefits or harms), present, for each study: (a) simple summary data for each } \\
\text { intervention group (b) effect estimates and confidence intervals, ideally with a forest plot. }\end{array}$ & $6-7$ \\
\hline Synthesis of results & 21 & $\begin{array}{l}\text { Present the main results of the review. If meta-analyses done, include for each, confidence intervals and measures of } \\
\text { consistency. }\end{array}$ & $6-7$ \\
\hline Risk of bias across studies & 22 & Present results of any assessment of risk of bias across studies (see Item 15). & 8 \\
\hline Additional analysis & 23 & Give results of additional analyses, if done (e.g., sensitivity or subgroup analyses, meta-regression [see Item 16]). & 8 \\
\hline \multicolumn{4}{|l|}{ DISCUSSION } \\
\hline Summary of evidence & 24 & $\begin{array}{l}\text { Summarize the main findings including the strength of evidence for each main outcome; consider their relevance to } \\
\text { key groups (e.g., healthcare providers, users, and policy makers). }\end{array}$ & 8 \\
\hline Limitations & 25 & $\begin{array}{l}\text { Discuss limitations at study and outcome level (e.g., risk of bias), and at review-level (e.g., incomplete retrieval of } \\
\text { identified research, reporting bias). }\end{array}$ & 10 \\
\hline Conclusions & 26 & Provide a general interpretation of the results in the context of other evidence, and implications for future research. & 10 \\
\hline \multicolumn{4}{|l|}{ FUNDING } \\
\hline Funding & 27 & $\begin{array}{l}\text { Describe sources of funding for the systematic review and other support (e.g., supply of data); role of funders for the } \\
\text { systematic review. }\end{array}$ & 11 \\
\hline
\end{tabular}



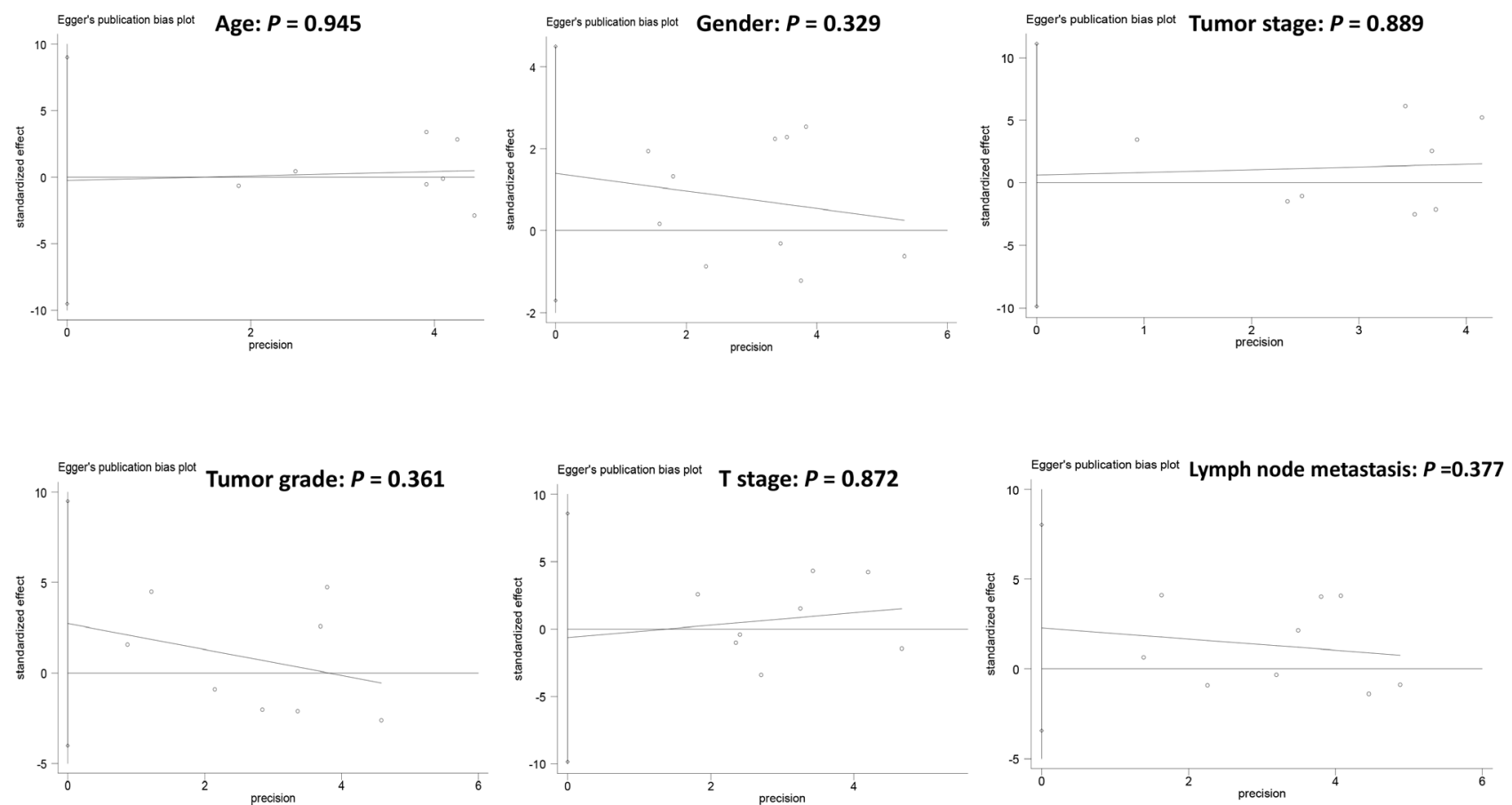

Supplementary Figure S3. Publication bias based on Egger's test. 